\title{
Nursery of the Black Tiger Shrimp Penaeus Monodon Postlarvae in a Biofloc System with Different Carbon Sources
}

\author{
Tran Ngoc Hai*, Chau Tai Tao, Tran Nguyen Duy Khoa, Ly van Khanh and Nguyen Thi Ngoc Anh \\ College of Aquaculture and Fisheries, Can Tho University, Vietnam
}

Submission: January 13, 2020; Published: February 06, 2020

Corresponding author: Tran Ngoc Hai, College of Aquaculture and Fisheries, Can Tho University, Campus II, $3 / 2$ street, Ninh Kieu district, Can Tho city, Vietnam,

Abstract

The experiment comprised five treatments including a control without any organic carbon addition and four different carbon sources applied in biofloc system namely sugar cane molasses, fine rice bran, cassava powder and combination of rice bran and cassava at an estimated C: $\mathrm{N}$ ratio of 12. The nursery phases were assessed in tanks with a volume of $450 \mathrm{~L}$ for 30 days. The black tiger shrimp (Penaeus monodon) postlarvae with an average weight of $0.01 \mathrm{~g}$ were randomly stocked at density of $600 \mathrm{Ind}^{-3} \mathrm{~m}^{-3}$. Results showed that carbohydrate addition resulted in better water quality and shrimp performance than that in the control system. Among the different carbon sources used, cassava and molasses have slightly increased the survival of shrimp. Overall, use of sugar cane molasses as carbon source seem to be more effective that gave better water quality, survival and production of shrimp.

Kewords: Biofloc; Cassava; Molasses; Rice bran; Biofloc; Penaeus monodon; Growth; Survival; Production

\section{Introduction}

The black tiger shrimp (Penaeus monodon) belongs to the family Penaeidae and is one of the most important species of Penaeus currently being cultured commercially in several countries and is of considerable commercial importance in international markets [1]. According to the Vietnamese Ministry of Agricultural and Rural Development (MARD), shrimp farming is one of the biggest industries in Vietnam, and the government is pushing to expand it, having announced plans to boost exports from US $\$ 3$ billion in 2016 to US $\$ 10$ billion by 2025. In 2017, shrimp farming area was estimated at nearly 705.9 thousand hectares. Shrimp yield production reached 701 thousand tons, an increase of $8.9 \%$ compared to the same period last year, of which black tiger shrimp were about 270.5 thousand tons [2]. The expansion of the shrimp farming industry was attributed mostly the success in the production of high quality postlarvae (PL) through nursery phase to ensure a high survival rate in grow-out ponds [3]. Application of a nursery can achieve stocking larger, healthier shrimp postlarvae and acclimate PLs to growout pond conditions. Nurseries also provide improved feeding efficiency, more controlled conditions than in ponds, and improve biosecurity and facility utilization. Therefore, establishment of high-quality rearing during nursery phase is the most important aspect for successful grow-out phase of shrimp [3-5].
Recently, biofloc technology (BFT) has been commonly applied in aquaculture system which focused on a more efficient use of nutrient input with limited or zero water exchange system and successful operation in nursery phase [6-10]. Moreover, BFT could provide extra food source with high value for the cultured shrimp [8-11]. Biofloc system can improve growth performance, improve water quality and enhance feed digestion and utilization of the cultured shrimp in zero-water exchange tanks that help reduction in the demand for water and discharge of effluents in the environment $[7,10,12]$. In biofloc system, bacteria and other microorganisms use carbohydrate as a food, to generate energy and to grow [11]. The addition of different carbohydrate sources to the culture system could affect formation of biofloc and efficiency of the system $[12,13]$. The present study evaluated the effects of different carbon sources on performance of $P$. monodon postlarvae during the nursery phase reared in biofloc systems, with the goal to determine the optimal carbon source for rearing for P. monodon in this system.

\section{Materials and Methods}

\section{Experimental Materials and Biofloc Formation}

The black tiger shrimp Penaeus monodon postlarvae 15 (PL15) from one single batch was obtained from an experimental 
hatchery at the Department of Coastal Aquaculture, College of Aquaculture and Fisheries, Can Tho University. Commercial feed (Grobest-GB640) is manufactured by Grobest \& me-MEI Company, Dong Nai province, Vietnam. According to the label, the nutritional contents of feed are $40 \%$ in protein, $6 \%$ in lipid, $14 \%$ in ash, $6 \%$ in fiber and $11 \%$ moisture. Sugar cane molasses was provided by the Can Tho Sugar Joint Stock Company, cassava powder and rice bran were purchased from local market. The carbon contents of these ingredients were $46.7 \%$ in sugar cane molasses, $83.0 \%$ in cassava powder and $50.0 \%$ in rice bran.

Biofloc formation: The formation of biofloc was begun with quantities of organic carbon sources recommended by Avnimelech [11]. Each ingredient was dissolved in freshwater and incubated for $48 \mathrm{~h}$ to stimulate the growth of heterotrophic bacteria, and then added to the culture tanks at a $12: 1 \mathrm{C} / \mathrm{N}$ ratio. Addition of carbohydrate was based on the amount of pellet feed provided to shrimp in three days according to the protein contents of feed [11].

\section{Experimental Design and Management}

A nursery of P. monodon PL15 in the biofloc system was conducted for 30 days in the shrimp hatchery of the College of Aquaculture and Fisheries, Can Tho University, Vietnam. The test was set up as a completely randomized design with three replicates per treatment. The experiment comprised five treatments including a control treatment without addition of carbohydrate and other four treatments with different carbohydrate sources added for biofloc development, namely sugar cane molasses, fine rice bran, cassava powder and combination of rice bran and cassava powder $(\mathrm{RB}+\mathrm{CA})$ with ratio of 1:1, respectively and at an estimated $\mathrm{C}: \mathrm{N}$ ratio of 12 . The rearing system was set up under a transparent roof with a natural photoperiod and at ambient temperature. The 500-L round plastic tanks filled with $450 \mathrm{~L}$ water with a salinity of 15 ppt. Water in the rearing tanks was continuously aerated to maintain the optimal contents of dissolved oxygen. Shrimp PL15 with an initial average body weight of $0.01 \mathrm{~g}$ and total length of $1.33 \mathrm{~cm}$ were randomly stocked at density of $600 \mathrm{PL} \mathrm{m}^{-3}$. Shrimp postlarvae were fed a commercial feed used for $P$. monodon in the form of powder and crumble, as recommended by producer. Feeding was applied four times per day $(6: 00,11: 00,16: 00$, and 20:00 h), and the amount of feed provided was adjusted based on the presence or absence of residual feed in the rearing tank, no water exchange during rearing period.

\section{Data collection}

\section{Water Quality and Microbial Parameters}

Temperature, $\mathrm{pH}$, and DO in the rearing tanks were measured twice a day at 7:00 and 14:00 $\mathrm{h}$ using a multi-channel meter (Mettler Toledo, USA). Alkalinity was recorded weekly using a test kit (Sera, Germany). The concentrations of total ammonia nitrogen (TAN) and $\mathrm{NO}_{2}^{-}$were analyzed weekly and chlorophyll a was monitored biweekly using the standard method of APHA (1998) [14]). The biofloc volume was determined biweekly from a liter of water in each rearing tank using Imhoff cones [15]. At the end of experiment, total heterotrophic bacteria and Vibrio counts in rearing water, in biofloc and in shrimp were evaluated. The total heterotrophic bacteria were determined by counting the colonies, which grew on Marine Agar plates with 1.0\% NaCl. Before plating each sample onto agar medium, serial dilutions were made in a physiological saline solution consisted of $0.9 \% \mathrm{NaCl}$ [16]. The total Vibrio was counted using TCBS media (seawater with thiosulfate citrate bile salts agar) by the spread plate technique [17]. Number of bacteria was expressed in colony-forming units per $\mathrm{mL}$ of water ( $\mathrm{CFU} \mathrm{mL} \mathrm{mL}^{-1}$ ) and per gram of biofloc or shrimp $\left(\mathrm{CFU} \mathrm{g}^{-1}\right)$. The proximate composition (moisture, protein, lipid and ash) of biofloc was analyzed according to the standard methods of the Association of Official Analytical Chemists AOAC (2000) [18]).

\section{Shrimp Performance}

The initial weight and length of shrimp PL were determined by randomly taking $60 \mathrm{PL}$ from the conditioning tank to measure individual weight and length. The final weight and length of shrimp were measured individually and counted to calculate survival at the termination of the experiment. The specific growth rate (SGR) in term of weight and length, survival, and production of shrimps were calculated using the following equations:

$\operatorname{SGR}_{\mathrm{w}}\left(\% /\right.$ day $\left.^{-1}\right)=((\ln$ final weight $)-(\ln$ initial weight $)) /$ Days of culture $\mathrm{x} 100$

$\operatorname{SGR}_{\mathrm{L}}\left(\% /\right.$ day $\left.^{-1}\right)=((\ln$ final length $)-($ ln initial length $)) /$ Days of culture $\mathrm{x} 100$

Survival $(\%)=$ Final number of shrimp/Initial number of shrimp x 100

Production (number of shrimp $\mathrm{m}^{-3}$ ) = Final number of shrimp/ culture volume

\section{Statistical Analysis}

All percentage values were normalized through an arcsine transformation before statistical treatment. For all treatments, results were analyzed statistically with one-way ANOVA analysis of variance to find the overall effect of the treatment (SPSS for Windows, Version 16.0). The Duncan test was used to detect differences between means at significant level of $\mathrm{p}<0.05$.

\section{Results}

\section{Water Quality Parameters}

The average daily water temperature and dissolved oxygen contents fluctuated in the ranges of $28.1-30.3^{\circ} \mathrm{C}$ and $5.7-6.1 \mathrm{mg}$ $\mathrm{L}^{-1}$, respectively. Water $\mathrm{pH}$ varied from 8.0 to 8.4 with alkalinity concentrations between 132 and $137 \mathrm{mg} \mathrm{CaCO}_{3} \mathrm{~L}^{-1}$ during experimental period (Table 1). Generally, these parameters did not 
differ greatly among treatments and were all in a suitable range for shrimp P. monodon growth [19]. Additionally, high alkalinity favors biofloc formation and the establishment of nitrifying bacteria in biofloc system [20]. The mean concentrations of chlorophyll $a(\mathrm{Chl} a)$ was in the range of 186-509 $\mu \mathrm{g} \mathrm{L}^{-1}$, of which the value in the cassava treatment was highest and significantly different $(p<0.05)$ from other treatments except the rice bran treatment. Biofloc volumes in the control treatment was lowest $\left(0.45 \mathrm{ml} \mathrm{L}^{-1}\right)$ and statistically different from the biofloc treatments (2.92-3.90 $\mathrm{ml} \mathrm{L}^{-1}$ ). When comparing among carbon source treatments, the value of biofloc volume in the cassava treatment was significantly lower than in other treatments (Table 1).

Table 1: Physico-chemical water parameters in the rearing tanks.

\begin{tabular}{|c|c|c|c|c|c|c|}
\hline \multicolumn{2}{|c|}{ Treatment } & Control & Molasses & Rice bran & Cassava & $\mathrm{RB}+\mathrm{CA}$ \\
\hline \multirow{2}{*}{ Temperature $\left({ }^{\circ} \mathrm{C}\right)$} & $7: 00 \mathrm{~h}$ & $28.1 \pm 1.0$ & $28.1 \pm 0.8$ & $28.0 \pm 0.9$ & $28.2 \pm 1.0$ & $28.1 \pm 0.9$ \\
\hline & $14: 00 \mathrm{~h}$ & $30.2 \pm 1.2$ & $30.1 \pm 1.3$ & $30.2 \pm 1.4$ & $30.3 \pm 1.3$ & $30.2 \pm 1.4$ \\
\hline \multirow{2}{*}{$\mathrm{pH}$} & $7: 00 \mathrm{~h}$ & $8.1 \pm 0.2$ & $8.0 \pm 0.2$ & $8.1 \pm 0.2$ & $8.1 \pm 0.2$ & $8.1 \pm 0.2$ \\
\hline & $14: 00 \mathrm{~h}$ & $8.4 \pm 0.1$ & $8.4 \pm 0.2$ & $8.3 \pm 0.2$ & $8.4 \pm 0.2$ & $8.3 \pm 0.2$ \\
\hline \multicolumn{2}{|c|}{ DO (mg/L) } & $5.9 \pm 0.4$ & $5.7 \pm 0.6$ & $6.1 \pm 0.3$ & $5.8 \pm 0.3$ & $5.7 \pm 0.4$ \\
\hline \multicolumn{2}{|c|}{ Alkalinity $\left(\mathrm{mg} \mathrm{CaCO}_{3} \mathrm{~L}^{-1}\right)$} & $137 \pm 13$ & $132 \pm 12$ & $136 \pm 15$ & $134 \pm 13$ & $133 \pm 17$ \\
\hline \multicolumn{2}{|c|}{ Chlorophyll a $\left(\mu \mathrm{g} \mathrm{L}^{-1}\right)$} & $293 \pm 126^{a}$ & $246 \pm 76^{a}$ & $324 \pm 119^{\mathrm{ab}}$ & $509 \pm 139^{b}$ & $186 \pm 74^{\mathrm{a}}$ \\
\hline \multicolumn{2}{|c|}{ Biofloc volume $\left(\mathrm{ml} \mathrm{L}^{-1}\right)$} & $0.45 \pm 0.14^{\mathrm{a}}$ & $3.58 \pm 0.33 b^{c}$ & $3.90 \pm 0.71^{c}$ & $2.92 \pm 0.72^{\mathrm{b}}$ & $3.02 \pm 0.19^{\mathrm{bc}}$ \\
\hline
\end{tabular}

Means within the same row sharing different superscripts are significantly different $(p<0.05)$

The concentrations of total ammonia nitrogen (TAN) in the biofloc treatments were highest at day 7 (1.12-1.49 $\left.\mathrm{mg} \mathrm{L}^{-1}\right)$, and then tended to decline sharply with culture period (0.11-0.59 $\mathrm{mg} / \mathrm{L}$ at day 28). On the contrary, the value of TAN in the control increased steadily during rearing period and varied from 0.52 $\mathrm{L}^{-1}$ at day 7 to $1.03 \mathrm{mg} \mathrm{L}^{-1}$ at day 28. The contents of $\mathrm{NO}_{2}^{-}$in the rearing tanks tended to increase with culture duration. These values were in the ranges of $0.07-0.24 \mathrm{mg} \mathrm{L}^{-1}$ and $0.70-1.41 \mathrm{mg} \mathrm{L}^{-1}$ at day 7 and day 28, respectively, of which the value in the control group were higher compared to those in the biofloc treatments during rearing period (Figure 1). When comparing among carbon source treatments, the contents of TAN and $\mathrm{NO}_{2}^{-}$in the molasses treatment were much lower than those in other treatments. Although the levels of TAN and $\mathrm{NO}_{2}^{-}$in the control tanks were highest at the end of the experiment, these values remain in acceptable range for development of Penaeus shrimp [21].

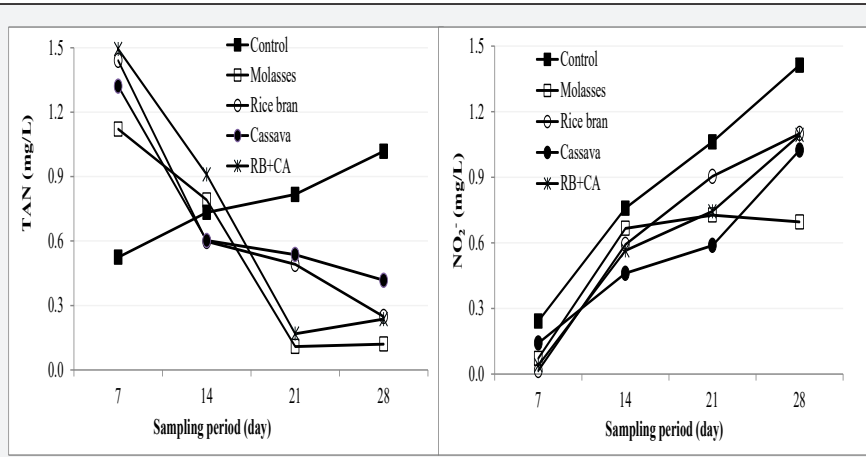

Figure 1: Variation in TAN and $\mathrm{NO}_{2}$ - concentrations during culture period.

\section{Evaluation of Microbial Load}

The microbial load in the rearing tanks, as investigated by total heterotrophic and Vibrio count (Table 2). Results showed that mean values of total heterotrophic bacterial (THB) counts in the water varied from 9.90 to $26.33 \times 10^{4} \mathrm{CFU} \mathrm{mL}^{-1}$, of which the values in the treatments of molasses and rice bran were significantly higher $(\mathrm{p}<0.05)$ than those in the control and the $\mathrm{RB}+\mathrm{CA}$ treatments but not significantly different from the cassava group. THB counts in biofloc samples were similar among treatments ( $\mathrm{p}>0.05$ ), ranging from 2.83 to $3.53 \times 10^{5} \mathrm{CFU} \mathrm{mL}^{-1}$. For experimental shrimp samples, the average THB counts were in the range of $7.5-30.9 \times 10^{5} \mathrm{CFU} \mathrm{mL}^{-1}$, in which the values in the cassava and $\mathrm{RB}+\mathrm{CA}$ were highest and statistical differences $(\mathrm{p}<0.05)$ from other treatments.

The total Vibrio count in the water samples of the molasses treatment was lowest $\left(4.4 \times 10^{3} \mathrm{CFU} \mathrm{\textrm {mL } ^ { - 1 }}\right)$ and significantly 
different $(\mathrm{p}<0.05)$ from the control $\left(12.4 \times 10^{4} \mathrm{CFU} \mathrm{mL}^{-1}\right)$ and other biofloc treatments, except the $\mathrm{RB}+\mathrm{CA}$ treatment. Total Vibrio count in the biofloc samples varied in the range of 1.57- $3.63 \times 10^{4}$ CFU $\mathrm{mL}^{-1}$, of which Virbio load in the molasses treatment was than those in the control and other carbon source treatments, statistical differences were only observed among the molasses, the rice bran and $\mathrm{RB}+\mathrm{CA}$ treatments $(\mathrm{p}<0.05)$. Vibrio count in shrimp samples from the control $\left(3.00 \times 10^{4} \mathrm{CFU} \mathrm{mL}^{-1}\right)$ and the rice bran treatment (3.13 x $10^{4} \mathrm{CFU} \mathrm{mL}^{-1}$ ) were highest, and significantly different $(\mathrm{p}<0.05)$ from the cassava and $\mathrm{RB}+\mathrm{CA}$ treatments.

\section{Proximate Composition of Biofloc}

The moisture content of biofloc was similar among treatmentS ( $p>0.05$ ), fluctuated from $80.10 \%$ to $84.47 \%$. The protein and lipid concentrations of biofloc varied in the range of $10.07-21.47 \%$ and $1.26-2.17 \%$, respectively, of which the values in the control group was lowest and statistical difference $(p<0.05)$ from the other treatments. The ash contents of biofloc was not affected by addition of different carbohydrate source ( $p>0.05)$, varying from $41.33 \%$ to $44.77 \%$ (Table 3 ).

Table 2: Mean values of total heterotrophic bacterial and Vibrio count in water, in biofloc and in shrimp samples.

\begin{tabular}{|c|c|c|c|c|c|}
\hline Treatment & Control & Molasses & Rice bran & Cassava & RB+CA \\
\hline \multicolumn{7}{|c|}{ Total heterotrophic bacteria count } \\
\hline \multicolumn{7}{|c|}{ Total Vibrio count } & $26.65 \pm 7.14^{\mathrm{b}}$ & $16.17 \pm 3.65^{\mathrm{ab}}$ & $11.63 \pm 4.23^{\mathrm{a}}$ \\
\hline In water $\left(10^{4} \mathrm{CFU} \mathrm{mL}^{-1}\right)$ & $9.90 \pm 4.03^{\mathrm{a}}$ & $26.33 \pm 9.80^{\mathrm{b}}$ & $3.37 \pm 0.23^{\mathrm{a}}$ & $3.40 \pm 0.82^{\mathrm{a}}$ & $3.53 \pm 0.60^{\mathrm{a}}$ \\
\hline In biofloc $\left(10^{5} \mathrm{CFU} \mathrm{mL}^{-1}\right)$ & $2.83 \pm 0.38^{\mathrm{a}}$ & $3.13 \pm 0.31^{\mathrm{a}}$ & $23.6 \pm 8.7^{\mathrm{b}}$ & $30.9 \pm 4.5^{\mathrm{b}}$ \\
\hline In shrimp $\left(10^{5} \mathrm{CFU} \mathrm{mL}^{-1}\right)$ & $8.6 \pm 0.4^{\mathrm{a}}$ & $10.2 \pm 0.8^{\mathrm{a}}$ & $27.8 \pm 1.3^{\mathrm{c}}$ & $12.3 \pm 3.2^{\mathrm{b}}$ & $8.8 \pm 3.7^{\mathrm{ab}}$ \\
\hline \multicolumn{7}{|c|}{} & $12.4 \pm 5.1^{\mathrm{b}}$ & $4.4 \pm 3.2^{\mathrm{a}}$ & $3.63 \pm 0.59^{\mathrm{b}}$ & $2.73 \pm 0.40^{\mathrm{ab}}$ & $3.43 \pm 0.80^{\mathrm{b}}$ \\
\hline In water $\left(10^{3} \mathrm{CFU} \mathrm{mL}^{\mathrm{b}}\right)$ & $2.67 \pm 1.52^{\mathrm{ab}}$ & $1.57 \pm 3.630 .47^{\mathrm{a}}$ & $3.13 \pm 1.43^{\mathrm{b}}$ & $1.57 \pm 0.40^{\mathrm{a}}$ & $1.20 \pm 0.17^{\mathrm{a}}$ \\
\hline In biofloc $\left(10^{4} \mathrm{CFU} \mathrm{mL}^{-}\right)$ & $3.00 \pm 0.56^{\mathrm{b}}$ & $2.33 \pm 0.15^{\mathrm{ab}}$ &
\end{tabular}

Means with different superscripts in the same row are significantly different $(p<0.05)$

Table 3: Proximate composition of biofloc (\% dry matter).

\begin{tabular}{|c|c|c|c|c|c|}
\hline Composition & Control & Molasses & Rice bran & Cassava & RB+CA \\
\hline Moisture & $83.80 \pm 2.26^{\mathrm{a}}$ & $84.47 \pm 2.25^{\mathrm{a}}$ & $80.10 \pm 3.18^{\mathrm{a}}$ & $84.27 \pm 3.46^{\mathrm{a}}$ & $83.90 \pm 3.20^{\mathrm{a}}$ \\
\hline Protein & $10.07 \pm 1.63^{\mathrm{a}}$ & $20.73 \pm 1.10^{\mathrm{b}}$ & $21.47 \pm 0.72^{\mathrm{b}}$ & $21.40 \pm 0.46^{\mathrm{b}}$ & $21.33 \pm 0.97^{\mathrm{b}}$ \\
\hline Lipid & $1.26 \pm 0.43^{\mathrm{a}}$ & $2.10 \pm 0.26^{\mathrm{b}}$ & $2.17 \pm 0.32^{\mathrm{b}}$ & $2.13 \pm 0.06^{\mathrm{b}}$ & $2.07 \pm 0.25^{\mathrm{b}}$ \\
\hline Ash & $44.77 \pm 4.62^{\mathrm{a}}$ & $41.33 \pm 1.80^{\mathrm{a}}$ & $42.83 \pm 0.64^{\mathrm{a}}$ & $41.48 \pm 0.74^{\mathrm{a}}$ & $42.04 \pm 0.81^{\mathrm{a}}$ \\
\hline
\end{tabular}

Means with different superscripts in the same row are significantly different $(p<0.05)$

\section{Growth, Survival and Production of Experimental Shrimp}

Growth performance, survival and production of shrimp after 30 days of rearing are shown in Table 4. Results indicated that the final length and specific growth rate in length $\left(\mathrm{SGR}_{\mathrm{L}}\right)$ of shrimps varied in the ranges of 3.35-3.99 $\mathrm{cm}$ and 3.07-3.66\% day $^{-1}$, respectively. Final weights of shrimps attained from 0.27 $\mathrm{g}$ to $0.42 \mathrm{~g}$, corresponding to the $\mathrm{SGR}_{\mathrm{w}}$ of $10.98-12.47 \%$ day $^{-1}$. Generally, growth performance of shrimp in the control group was significantly poorer $(\mathrm{p}<0.05)$ than those in the biofloc treatments. Survival of shrimp fluctuated between $89.3 \%$ and $92.9 \%$, which was equivalent to production of 536-558 Ind. $\mathrm{m}^{-3}$. Although the molasses treatment gave relatively higher survival and production than in the control and other biofloc treatments, statistical difference was not found among treatments $(\mathrm{p}>0.05)$.

\section{Discussion \\ Water Quality and Microbial Parameters}

Application of different carbon source (molasses, cassava, rice bran and rice bran combined with cassava) was adequate in maintaining the overall water quality parameters in a normal range for shrimp growth in the biofloc system. Previous finding revealed that biofloc has the capability to reduce the concentration of ammonia in the culture system because the heterotrophic bacteria in biofloc can absorb ammonia 40 times faster than nitrification bacteria [22]. Furthermore, biofloc grown in the bioreactor can convert $98 \%$ ammonia to nitrate at a concentration of $110 \mathrm{mg} \mathrm{L}^{-1} \mathrm{day}^{-1}$ [23]. In the current study, the low value of nitrite in the biofloc treatments probably due to the ammonia has been converted to nitrite by heterotrophic bacteria in biofloc then utilized by microalgae for growing [11,22]. This exhibited that the nitrification process took place in the culture 
medium. According to Reynolds [23], the nitrification process involves in two steps and each step is carried out by a specific group of nitrifying organisms, in which ammonia is oxidized to nitrite and then nitrite is oxidized to nitrate by nitrification bacteria. Other study reported that the black tiger shrimp (Penaeus monodon) reared in biofloc system, water quality in the rearing tanks was improved as indicated by the concentrations of TAN, nitrite and nitrate in biofloc treatments were significantly lower than in the control [24]. The results in the present study are in accordance with previous investigation mentioned above, water quality in biofloc treatments were better than that in the control.

Table 4: Average values of growth rate, survival and production of $P$. monodon postlarvae reared in a biofloc system with different carbon sources for 30 days.

\begin{tabular}{|c|c|c|c|c|c|}
\hline Treatment & Control & Molasses & Rice bran & Cassava & $\mathrm{RB}+\mathrm{CA}$ \\
\hline Initial length $(\mathrm{cm})$ & $1.33 \pm 0.09$ & $1.33 \pm 0.09$ & $1.33 \pm 0.09$ & $1.33 \pm 0.09$ & $1.33 \pm 0.09$ \\
\hline Final length $(\mathrm{cm})$ & $3.35 \pm 0.25^{\mathrm{a}}$ & $3.68 \pm 0.05^{b}$ & $3.60 \pm 0.21^{\mathrm{ab}}$ & $3.99 \pm 0.10^{c}$ & $3.79 \pm 0.01 b^{c}$ \\
\hline SGRL (\% day $\left.{ }^{-1}\right)$ & $3.07 \pm 0.24^{\mathrm{a}}$ & $3.39 \pm 0.04 b^{c}$ & $3.32 \pm 0.20^{\mathrm{ab}}$ & $3.66 \pm 0.08^{c}$ & $3.49 \pm 0.01 b^{c}$ \\
\hline Initial weight (g) & $0.012 \pm 0.005$ & $0.012 \pm 0.005$ & $0.012 \pm 0.005$ & $0.012 \pm 0.005$ & $0.012 \pm 0.005$ \\
\hline Final weight (g) & $0.27 \pm 0.05^{\mathrm{a}}$ & $0.36 \pm 0.03^{\mathrm{bc}}$ & $0.34 \pm 0.06^{\mathrm{ab}}$ & $0.42 \pm 0.02^{\mathrm{c}}$ & $0.38 \pm 0.03^{\mathrm{bc}}$ \\
\hline SGRW (\% day $\left.{ }^{-1}\right)$ & $10.98 \pm 0.60^{\mathrm{a}}$ & $11.92 \pm 0.26^{b}$ & $11.74 \pm 0.57^{b}$ & $12.47 \pm 0.18^{\mathrm{b}}$ & $12.10 \pm 0.27^{b}$ \\
\hline Survival (\%) & $89.3 \pm 1.7^{\mathrm{a}}$ & $92.9 \pm 1.7^{\mathrm{a}}$ & $90.4 \pm 2.3^{\mathrm{a}}$ & $91.1 \pm 3.4^{\mathrm{a}}$ & $89.6 \pm 1.7^{\mathrm{a}}$ \\
\hline Production (Ind. $\mathrm{m}^{-3}$ ) & $536 \pm 10^{\mathrm{a}}$ & $558 \pm 10^{\mathrm{a}}$ & $543 \pm 14^{\mathrm{a}}$ & $547 \pm 20^{\mathrm{a}}$ & $538 \pm 10^{\mathrm{a}}$ \\
\hline
\end{tabular}

Means with different superscripts in the same row are significantly different $(p<0.05)$

Chlorophyll $a(\mathrm{Chl} a)$ represents $1-2 \%$ of total algal dry weight and can thus be a good representation of microalgae abundance [25]. In our study, Chl $a$ varied largely among treatments this could be due to various conditions of availability of nutrients either from the decomposition of accumulated organic matter from addition of different carbon sources or from uneaten feed that caused development of algae in the rearing tanks. Previous studies reported that microalgae are common inhabitants in biofloc, they can live as free cell into the water column or could form aggregates even in a heterotrophic bacterium dominated $[26,27]$. The concentrations of Chl $a$ in the current study was lower than in the study of Rajkumar et al. [28], they obtained Chl $a$ level of $553.67 \mu \mathrm{g} \mathrm{L}^{-1}$ in biofloc system. In our study, the Chl $a$ level was very low in most treatments due to the limited light and the presence of carbon source in the culture tanks. According to Ju et al. [29], supply of carbon source in the biofloc system favors the microbial growth rather than microalgae, and the utilization of carbon sources by heterotrophic bacteria to control ammonia in the rearing tanks which promotes succession and dominance of bacteria over microalgae.

The addition of organic carbon sources in biofloc system, the formation of biofloc is constant in these systems that facilitate the development of biofloc [11]. Duration of the present study lasted for 30 days, lower biofloc volume levels was recorded as compared to the results obtained from Rajkumar et al [28], author reported that the biofloc development in the first 30 days was slow owing to the clean surfaces of the tank, the formation of adhesiveness of the biofloc could develop slowly in the initial period. Other study revealed that formation of bioflocs are accumulation of algae, bacteria, protozoan, and other kinds of particulate organic matter such as feces and uneaten feed which are held together in a loose matrix of mucus secreted by bacteria and bound by filamentous algae or held by electrostatic attraction [30]. In the current study, the total heterotrophic bacterial (THB) count from water, biofloc and shrimp samples in the biofloc treatments were higher than in the control treatment.

This indicated that the addition of different organic carbon contributed toward the development of bacteria in the culture system. Similar finding was reported by Hari et al. [31], carbohydrate addition influenced the THB in the water column and sediment, utilization of molasses as carbon source beneficially affected the survival and proliferation of the THB. Moreover, supplementation of probiotic and molasses in the recirculating system for rearing vannamei shrimp, the concentrations of THB in surface and bottom water and sediment, and shrimp samples were always much higher than those observed for the control group [32]. The THB count in the biofloc treatments in the present study was lower than that reported by Rajkumar et al. [28]. In this study, most of samples in in the biofloc treatments had lower total Vibrio count as compared with the control group. This supports the study of Emerenciano et al. [33], the natural probiotic in the biofloc could internally or externally against the pathogenic Vibrio sp. from giving detrimental to the shrimp.

Competing with the dominant heterotrophic bacteria and nitrifying bacteria for the essential nutrients such as nitrogen that can limit the development of Vibrio sp. group in the culture tanks. Similar confirmation reported by Manan et al. [34], the Vibrio sp. was detected in the biofloc aggregation but in less CFU number than THB count. These concentrations were not harmful to the shrimps as it is being controlled by the biofloc itself through higher abundance of microalgae and can compete with large number of 
THB. Previous studies reported that nutrient value of biofloc greatly influenced by carbon source, environmental conditions and bacteria communities [11,35]. Proximate composition of biofloc varied in the ranges of $12-50 \%$ for crude protein, 0.5 $12.5 \%$ crude lipid, and $13-46 \%$ ash [11]. The biofloc can contain high levels of crude protein and other nutrients such as essential fatty acids and amino acids [8,10]. Microorganisms present in BFT system played an important role for provision of essential nutrients for shrimp. Therefore, the nutritional benefits of biofloc serve as a natural food source for shrimp [6].

\section{Shrimp Performance}

Although no significant differences were found on survival but there were significant differences in specific growth rate in term of weight between the biofloc and the control treatments. These results illustrate that the appropriate amount of carbohydrate added to the rearing tanks resulted in the interaction effects of the better water quality and higher bacterial densities that created optimal conditions for good growth and survival of $P$. monodon in the current study. Other investigations revealed that carbohydrate addition can result in the formation and accumulation of bioflocs $[6,12]$ which could serve as an important food source for the zooplankton and thus could increase the growth of the shrimp. Further, carbohydrate supplementation can lead to increase in protein utilization and supply of essential lipids and vitamins for the growth of shrimp $[6,8]$.

BFT improves water quality through microbial manipulation, thereby facilitating good growth of cultured shrimp, under a zerowater exchange system, the addition of carbohydrate stimulates the development of diverse and balanced microbial communities originating from the rearing water [34].These active and dense microorganisms together with suspended organic particles tend to form the biofloc, which can continuously be consumed by the shrimp as a natural food source [28,34]. Application of BFT apart from maintaining good water quality, the established biofloc in the culture system could improve feed utilization, thereby increasing growth performance of cultured species. Similarly, BFT applied in shrimp farming enhanced growth performance, and survival of shrimp [13,36]. Further, the addition of carbon source promotes higher natural bacterial protein biomass and enhances shrimp growth in the biofloc systems [37]. Our results are in line with various literatures mentioned above.

Regarding carbon sources in this study, the addition of rice bran in the rearing tanks resulted in poorer growth of shrimp than other carbon sources. Additionally, no distinct differences in growth rates of shrimp were observed among the molasses, cassava and combination of rice bran and cassava groups. In early study, the use of wheat flour for the biofloc production could effectively enhance the biofloc production and contributed towards good water quality which resulted in higher production of shrimp because the wheat flour has easily digestible and available carbon for the growth of microorganism [28]. Several researchers suggested that the use of carbon sources in BFT should be obtained from by-products derived from human and animal food industry, preferentially cheap and local available. Cheap sources of carbohydrates such as molasses, glycerol, and plant meals (i.e., wheat, corn, rice, tapioca...).

Local available carbon sources should be assessed but bacteria assimilation's characteristics will definitely need to take into consideration. Monosaccharide and oligosaccharide simple carbohydrate-rich types (i.e., glucose, sucrose-rich sugars...) versus polysaccharide complex-rich types (i.e., starch and cellulose) will lead different bacteria assimilations, nutritional value and their development [11,12,28,33]. Similarly, Asaduzzaman et al. [38] suggested the utilization of low-cost carbon sources should be applied in BFT because it made high economic efficiency and provided an additional source of protein and improved the nutritional efficiency of the culture system. According to earlier findings, sugar cane molasses added in BFT system, this carbon source is easily dissolved in the environment culture, and rapidly release carbon that serves as food source for heterotrophic bacteria in the environment, which occurs simultaneously with the increase in the production in the culture system $[4,39]$.

Overall, it was observed that the use of sugar cane molasses and cassava as carbon source was more effective than other carbon types in this study. When comparing molasses with cassava powder, addition of molasses in the culture tank resulted in better water quality (lower TAN, $\mathrm{NO}_{2}^{-}$and Vibrio count) than that in the cassava tanks. In practice, sugar cane molasses is one of the cheapest carbohydrate sources in Vietnam. Therefore, this substance could be considered the appropriate carbon source for applying in nursery of $P$. monodon postlarvae.

\section{Conclusion}

All carbon sources (sugar cane molasses, rice bran, cassava and combination of rice bran and cassava) applied in the biofloc system for rearing P. monodon postlarvae were efficient in the formation of bioflocs, reducing the concentration of TAN and $\mathrm{NO}_{2}{ }^{-}$and consequently improving the water quality and shrimp performance. Molasses and cassava powder were more effective than other carbon sources, of which molasses could be the most suitable carbon source that gave better water quality, survival and production of shrimp.

\section{Acknowledgment}

This study is funded by the project coded KHCN-TNB.ĐT/14$19 /$ C07. The authors wish to thank the staffs and students in the College of Aquaculture and Fisheries, Can Tho University for their assistance during the experiment. 


\section{References}

1. FAO (2016) Fisheries and Aquaculture topics. The State of World Fisheries and Aquaculture (SOFIA) (Food and Agriculture Organization United Nations).

2. MARD (2018) Vietnamese aquaculture sector in 2017.

3. Arnold S J, F E Coman, C J Jackson, S A Groves (2009) High intensity, zero water-exchange production of juvenile tiger shrimp, Penaeus monodon: an evaluation of artificial substrates and stocking density. Aquaculture 293(1-2): 42-48.

4. Souza D MD, S M Suita, L A J Romano, E L C Ballester (2014) Use of molasses as a carbon source during the nursery rearing of Farfantepenaeus brasiliensis (Latreille, 1817) in a biofloc technology system. Aquaculture Research 45(2): 270-277.

5. Khanjani M H, M M Sajjadi, M Alizadeh, I Sourinejad (2016) Study on nursery growth performance of Pacific white shrimp (Litopenaeus vannamei Boone, 1931) under different feeding levels in zero water exchange system. Iranian Journal of Fisheries Sciences 15(4): 14651484.

6. Emerenciano M, E L C Ballester, R O Cavalli, W Wasielesky (2012) Biofloc technology application as a food source in a limited water exchange nursery system for pink shrimp Farfantepenaeus brasiliensis (Latreille, 1817). Aquaculture Research 43(3): 447-457.

7. Faizullah M M, C B T Rajagopalsamy, B Ahilan, N Daniel (2019) Application of biofloc technology (BFT) in the aquaculture system. Journal of Entomology and Zoology Studies 7(4): 204-212.

8. Crab R, B Chielens, M Wille, P Bossier, W Verstraete (2010) The effect of different carbon sources on the nutritional value of bioflocs, a feed for Macrobrachium rosenbergii postlarvae. Aquaculture Research 41(4): 559-567.

9. Wasielesky W J, C Froes, G Foes, D Krummenauer, G Lara, et al. (2013) Nursery of Litopenaeus vannamei reared in a biofloc system: the effect of stocking densities and compensatory growth. Journal of Shellfish Research 32(3): 799-806.

10. Avnimelech Y (2009) Biofloc technology. In: The World Aquaculture Society, Baton Rouge, Louisiana, US, Pp. 182.

11. Serra F P, C A P Gaona, P S Furtado, L H Poersch, W J Wasielesky (2015) Use of different carbon sources for the biofloc system adopted during the nursery and grow-out culture of Litopenaeus vannamei. Aquaculture International 23(6): 1325-1339.

12. Ekasari J, Azhar, M H Surawidjaja, E H Nuryati, S De Schryver, et al. (2014) Immune response and disease resistance of shrimp fed biofloc grown on different carbon sources. Fish Shellfish Immunol 41(2): 332339.

13. APHA (1998) Standard methods for the examination of water and wastewater. The Association, Washington, DC.

14. Avnimelech Y, M Kochba (2009) Evaluation of nitrogen uptake and excretion by tilapia in biofloc tanks, using $\mathrm{N}^{15}$ tracing. Aquaculture 287(1): 163-168.

15. Sohier L P, M A G Bianchi (1985) Development of a heterotrophic bacterial community within a closed prawn aquaculture system. Microbial Ecology 11(4): 353-369.

16. Harris L, Owens, L Smith (1996) A selective and Differential Medium for Vibrio harveyi. Journal of Applied Environmental Microbiology 62(9): 3548-3550.

17. AOAC (2000) Official Methods of Analysis. Association of Official Analytical Chemists Arlington.
18. Solis N B (1988) Biology and ecology. In: Biology and culture of Penaeus monodon, SEAFDEC Aquaculture Department, Tigbauan, Philippines Pp. 3-36.

19. Furtado P S, L H Poersch, W J Wasielesky (2014) The effect of different alkalinity levels on Litopenaeus vannamei reared with biofloc technology (BFT). Aquaculture International 23(1):345-358.

20. Shailender M, C H Suresh-Babu, B Srikanth, B Kishor, D Silambarasan, et al. (2012) Sustainable culture method of giant black tiger shrimp, Penaeus monodon (Fabricius ) in Andhra Pradesh, India. IOSR Journal of Agriculture and Veterinary Science 1(3): 12-16.

21. Ebeling J M, M B Timmons, J J Bisogni (2006) Engineering analysis of the stoichiometry of photoautotrophic, autotrophic, and heterotrophic removal of ammonia-nitrogen in aquaculture systems. Aquaculture 257(1-4): 346-358.

22. De Schryver P, W Verstraete (2009) Nitrogen removal from aquaculture pond water by heterotrophic nitrogen assimilation in lab-scale sequencing batch reactors. Bioresource Technology 100(3): 11621167.

23. Reynolds T D, P A Richards (1996) Unit operations and processes in environmental engineering. In: $2^{\text {nd }}(E d n)$. Boston, Massachusetts, US.

24. Nurhatijah N, Z A Muchlisin, M A Sarong, A Supriatna (2016) Application of biofloc to maintain the water quality in culture system of the tiger prawn (Penaeus monodon). AACL Bioflux 9(4): 923-928.

25. Smith V H (2006) Responses of estuarine and coastal marine phytoplankton to nitrogen and phosphorus enrichment. Limnology Oceanography 51(1-2): $377-384$.

26. Decamp O, L Conquest, J Cody, I Forster, A G Tacon (2007) Effect of shrimp stocking density on size-fractionated phytoplankton and ecological groups of ciliated protozoa within zero-water exchange shrimp culture systems. Journal of the World Aquaculture Society 38(3): 395-406.

27. Ray J A, G Seaborn, W J Leffler, B S Wilde, A Lawson, et al. (2010) Characterization of microbial communities in minimal-exchange, intensive aquaculture systems and the effects of suspended solids management. Aquaculture 310(1-2): 130-138.

28. Rajkumar M, K P Pandey, R Aravind, A Vennila, V Bharti, et al. (2015) Effect of different biofloc system on water quality, biofloc composition and growth performance in Litopenaeus vannamei (Boone, 1931). Aquaculture Research 47(112): 3432-3444.

29. Ju Z Y, I Forster, L Conquest, W Dominy, W C Kuo, et al. (2008) Determination of microbial community structures of shrimp floc cultures by biomarkers and analysis of floc amino acid profiles. Aquaculture Research 39(2): 118-133.

30. Hargreaves J A (2013) Biofloc production systems for aquaculture. SRAC, Southern Regional Aquaculture Center Publication 4503: 1-12.

31. Hari B, M B Kurup, J T Varghese, J W Schrama, M C J Verdegem (2006) The effect of carbohydrate addition on water quality and the nitrogen budget in extensive shrimp culture systems. Aquaculture 252(2-4): 248-263.

32. De Paiva-Maia E, G Alves-Modesto, L Otavio-Brito, A Olivera, T C Vasconcelos-Gesteira (2013) Effect of a commercial probiotic on bacterial and phytoplankton concentration in intensive shrimp farming (Litopenaeus vannamei) recirculation systems. Latin American Journal of Aquatic Research 41(1): 126-137.

33. Emerenciano M, G Gaxiola, C Gerard (2013) Biofloc Technology (BFT): a review for aquaculture application and animal food industry. Biomass Now Cultivation Utilization. 
34. Manan H, J H Z Moh, N A Kasan, S Suratman, Mhd Ikhwanuddin (2017) Identification of biofloc microscopic composition as the natural bioremediation in zero water exchange of Pacific white shrimp, Penaeus vannamei, culture in closed hatchery system. Applied Water Science 7(5): 2437-2446.

35. Kuhn D D, A L Lawrence, G D Boardman, S Patnaik, L Marsh, et al (2010) Evaluation of two types of bioflocs derived from biological treatment of fish effluent as feed ingredients for Pacific white shrimp, Litopenaeus vannamei. Aquaculture 303(1-4): 28-33.

36. Ray A J, K S Dillon, J M Lotz (2011) Water quality dynamics and shrimp (Litopenaeus vannamei) production in intensive, mesohaline culture systems with levels of biofloc management. Aquacultural Engineering 45(3): 127-136
37. Panigrahi A, M Sundaram, S Chakrapani, S Rajasekar, J S Dayal, et al. (2019) Effect of carbon and nitrogen ratio (C:N) manipulation on the production performance and immunity of Pacific white shrimp Litopenaeus vannamei (Boone, 1931) in a biofloc-based rearing system. Aquaculture Research 50(1): 29-41.

38. Asaduzzamana M, M AWahab., M C J Verdegem, R K Adhikarya, S M S Rahmana, et al. (2010) Effects of carbohydrate source for maintaining a high C:N ratio and fish driven re-suspension on pond ecology and production in periphyton-based freshwater prawn culture systems. Aquaculture 301(1-4): 37-46.

39. Schneider O, V Sereti, E H Eding, J A J Verreth (2006) Molasses as C source for heterotrophic bacteria production on solid fish waste. Aquaculture 261: 1239-1248.

Your next submission with Juniper Publishers will reach you the below assets

- Quality Editorial service

- Swift Peer Review

- Reprints availability

- E-prints Service

- Manuscript Podcast for convenient understanding

- Global attainment for your research

- Manuscript accessibility in different formats

( Pdf, E-pub, Full Text, Audio)

- Unceasing customer service

Track the below URL for one-step submission https://juniperpublishers.com/online-submission.php 